\title{
Developing Sustainable Education Disposition Scale and Teacher Views regarding the Education Disposition *
}

\begin{tabular}{ccc}
\hline Article Type & Received Date & Accepted Date \\
Research & 15.11 .2018 & 23.12 .2019 \\
\hline
\end{tabular}

\section{Fatma Köybaşı Şemin**}

\begin{abstract}
This study aimed at developing a scale to measure the level at which schools stand for offering sustainable education. In addition, it was aimed to examine teachers' views on sustainable education disposition against school type or gender. This study is a descriptive survey and consists of two stages. As the first step, a sustainability scale was developed by the researcher to determine the level of sustainable education. Exploratory and confirmatory factor analyzes along with reliability checks were conducted. Explanatory factor analysis was performed with the data from 209 teachers working at schools in Şarkışla and Y1ldızeli districts and the scale was found to be one-dimensional with 32 items. Following the explanatory process, the scale was applied to 152 participants in Suşehri district for confirmatory factor analysis. The latter analysis was performed on the data obtained from the study group and the goodness-of-fit test was found within the acceptable limits. According to results, it can be inferred that the teachers have a high level of disposition to sustainable education. It was found out that teachers' views on sustainable education disposition differ between genders in favor of males.
\end{abstract}

Keywords: Sustainability, sustainable education, sustainable education disposition.

\footnotetext{
* This study is a part of the CUBAP project with project code of EĞT-068 in Cumhuriyet University.

** Dr. , Sivas Cumhuriyet University, Faculty of Education, Education Administration, Sivas, Turkey.

E-mail: fkoybasi@cumhuriyet.edu.tr, https://orcid.org/0000-0002-8684-1235
} 


\title{
Sürdürülebilir Ĕgitim Eğilimi Ölçeği Geliştirme ve Sürdürülebilir Eğitim Eğilimine İlişkin Öğretmen Görüşleri*
}

\begin{tabular}{ccc}
\hline Makale Türü & Başvuru Tarihi & Kabul Tarihi \\
Araştırma & 15.11 .2018 & 23.12 .2019 \\
\hline
\end{tabular}

\section{Fatma Köybaşı Şemin**}

\begin{abstract}
Öz
$\mathrm{Bu}$ çalışma, okulların sürdürülebilir eğitim eğilimi düzeyini ölçmek için bir ölçek geliştirmeyi amaçlamaktadır. Ayrıca, öğretmenlerin sürdürülebilir eğitim eğilimine yönelik görüşlerinin okul türüne ve cinsiyetine göre incelenmesi amaçlanmıştır. Bu çalışma betimsel bir çalışma olup iki aşamadan oluşmaktadır. Birinci aşamada, sürdürülebilir eğitim eğilim düzeyini belirlemek için araştırmacı tarafından bir sürdürülebilir eğitim eğilimi ölçeği geliştirilmiştir. Güvenirlik analizleri ile birlikte açımlayıcı ve doğrulayıcı faktör analizi yapılmıştır. Şarkışla ve Yıldızeli ilçelerinde bulunan okullarda çalışan 209 öğretmenin verileriyle açıklayıcı faktör analizi yapılmıştır ve ölçeğin 32 maddeyle tek boyutlu olduğu saptanmıştır. Açıklayıcı faktör analizi sürecinin ardından ölçek, doğrulayıcı faktör analizi için Suşehri ilçesindeki 152 katılımcıya uygulanmış ve uyum iyiliği testi kabul edilebilir değerler aralığına olduğu tespit edilmiştir. Elde edilen verilere göre, öğretmenlerin sürdürülebilir eğitime karşı yüksek düzeyde bir ilgileri olduğu sonucuna varılmıştır. Öğretmenlerin sürdürülebilir eğitim konusundaki görüşlerinin cinsiyetler arasında erkeklerin lehine farklılık gösterdiği bulunmuştur.
\end{abstract}

Anahtar Sözcükler: Sürdürülebilirlik, sürdürülebilir eğitim, sürdürülebilir eğitim eğilimi.

\footnotetext{
* Bu çalışma, Cumhuriyet Üniversitesi'nde yürütülen EĞT-068 kodlu CUBAP projesinin bir parçasıdır.

**Dr., Sivas Cumhuriyet Üniversitesi, Eğitim Fakültesi, Eğitim Yönetimi, Sivas, Turkey. E-posta: fkoybasi@cumhuriyet.edu.tr, https://orcid.org/0000-0002-8684-1235
} 


\section{Introduction}

The concept of sustainability means providing sufficient and necessary conditions for continuation of the ecosystem cycle. Chapin, Torn, and Tateno (1996) describe sustainability as the ability to transfer the functions and cyclic mobility of ecological systems into the future. Social and cultural aspects of sustainability as well as the interrelation and interaction among all fields (social, environmental, and economic) in which it relates (Blowers, 2003; Sachs, 1997) show that human factor has multidimensional needs. In other words, sustainability not only focuses on the environmental impact but also comprises of the dimensions of "environment", "economy", and "social welfare" where the society needs to find the equilibrium or even the optimum level (Brand, 2002). On the other hand, without limiting the ability to meet the needs of future generations, it also explains an improvement that can meet the needs of today's unspoiled environment, social justice, and economic prosperity (Finkbeiner, Schau, Lehmann \& Traverso, 2010).

Education is considered as one of the most important factors that will play a mediating role in enabling generations to meet the conditions required by a sustainable life (UNESCO, 2009; Lenz, 2013; Wheeler \& Bijur, 2000; Chalkley, Haigh \& Higgitt, 2013). Education aims to provide individuals with the behaviours they will exhibit in their lives. There are also cases where all the desired behaviours are not put into practice in an individual's life. In this case, such issues arise as intriguing topics as how much of the educational objectives can be achieved and whether the behaviours that will bring an individual's life to the optimum level have been achieved as an objective of education.

Sustainable education means the ability to put into practice students' behaviours which are referred to as attainments in the process of education and instruction through a holistic approach in social, economic, and ecological terms. Sustainable education refers to a paradigm which ensures understanding of the social, economic, and ecological system of the world order and offers behaviours that help survival of these systems. Sterling (2001) states that relational and contextual education and learning assure sustainability as human and natural forces are tightly connected. He also emphasizes that sustainability of education is also necessary for sustainable living. Findings which mandate a transformed educational paradigm are the change in the nature of economy and increased lack of control as a result of a lax implementation of student-centred education (Resnick \& Hall, 2016). To put into other words, Sterling (2001) lists the obstacles to the paradigm shift in education or realization of sustainable education as the failure to fully implement a constructivist education method through imposing and narration and problems arising from educational policies.

It can be clearly said that the reasons for failing to achieve sustainable education can be explained by the teaching methods as well as external factors (economic, external powers, etc.) besides educational policies. Tyack (1974) and Cohen (1988) pointed out that the desired positive changes have not been observed with weighted focus on educational administration, accountability and bureaucracy for the ultimate goal of improving education. It also seems contradictory to the system approach to expect a better quality of education through improvement of one single component of education. Sustainable education is about foreseeing that every single individual may have an effect on one other in all dimensions (economic, sociological, ecological, etc.) by virtue of the education offered at schools. In addition, it refers to the standpoint to see through a holistic perspective that we are shaping with our own hands the world in which we live all together. Resnick and Hall (2016) argue that it also puts education into a dead-end that every single parent demands schooling focusing on opportunities for their own child(ren) rather than an overall better education. A variety of educational reformation initiatives for such educational problems have been crippled because of the public resistance against reforms together with the organizational structure limiting such changes (Resnick and Hall, 2016). To start with, ways to remove obstacles should be sought for a change towards sustainable education. Deficiencies and faults in the path of sustainable education should be identified. In this context, dimensions of sustainable education and the current extent at each of these dimensions should be identified. Becker and Chiswick (1966) underlined that education is a long-term investment and thus related policies will take longer. Uhl, Kulakowski, Gerwing, Brown and Cochrane (1996) point out that governments must struggle towards training university students in contact with real-life situations through case studies, problem-oriented research, and similar methods so that the future can be shaped by smart, wise, and well-educated individuals. They further suggest that if engineers, businessmen, public employees, 
teachers, artists, and scientists are trained through this education, they can be prepared to face the future world problems. The concepts which build up sustainable education are given in Figure 1. (The mentioned elements of rationales are included in the scale as items).

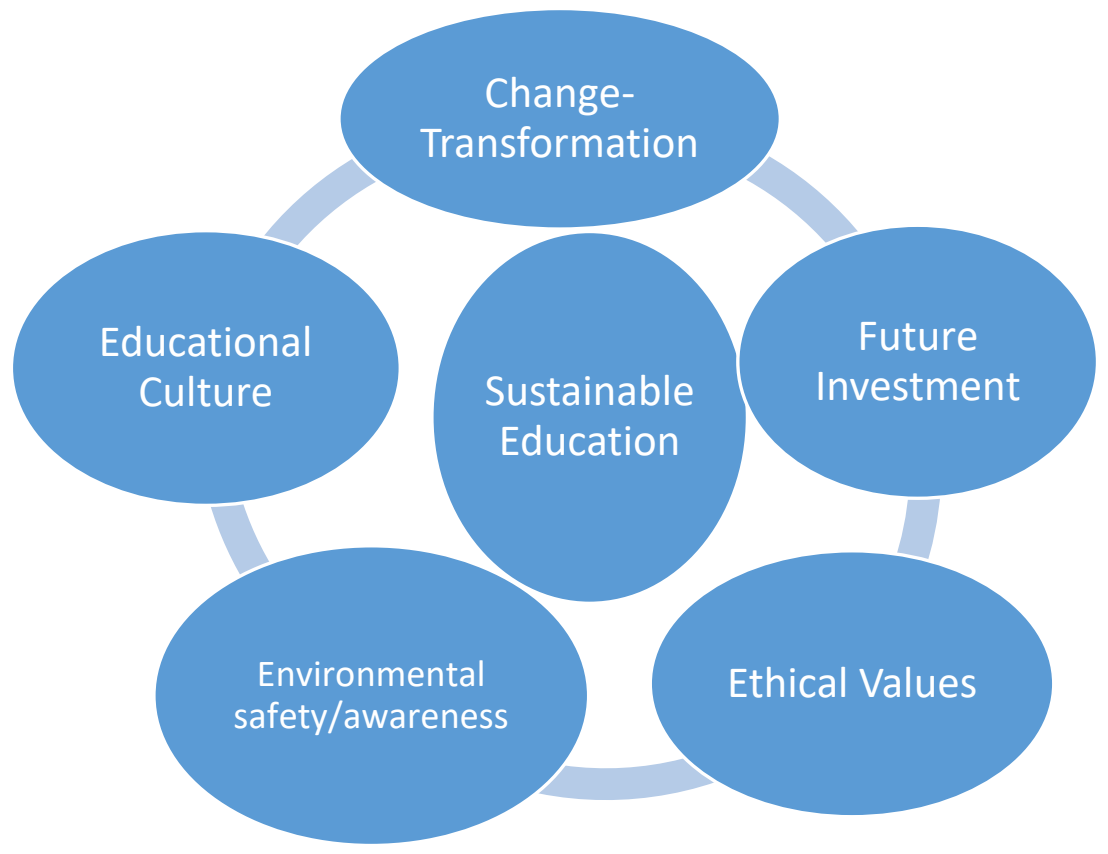

Figure 1. Components of Sustainable Education

During the literature review for this study, only a limited amount of literature was accessed because of our focus on the concept of education for sustainability rather than sustainable education (Sterling, 2001). In a prospect of the literature, it is noted that Cebrian and Junynet (2015) investigated university students' views about their competences in education for sustainable development. In another study; Wolff, Sjöblom, Hofman-Bergholm and Palmberg (2017) found out that teachers' education seems to be lagging the needs for sustainability. On the other hand; Andersson, Jagers, Lindskop and Martinsson (2013) found out that sustainable development program increased awareness level of prospective teachers about sustainability. Apart from that; Pauw, Gericke, Olsson and Berglund, (2015) analyzed students' awareness of sustainable development at grades 6, 9, and 12. Spahiu and Lindemann-Matthies (2015) explored the positive effect of teachers' workshop on sustainable development.

Differently from the preceding ones, this study was intended to unearth the sustainable education disposition, which sets out the capacity of school education (goal, content, policy, method etc.) to serve sustainable development. There is currently a research gap concerning a measurement tool in this particular field. Furthermore, the measurement tool developed in this study could allow access to information that will strengthen the sustainable education in the light of the teachers' opinions on sustainable education disposition.

The first step to clarify this issue and turning it into a concrete theory will be to determine the scope of sustainable education. In this study, it was preferred to examine sustainable education in a more limited area based on the related literature. In order to identify sustainable education profile of schools; first, the contents forming sustainable education were tried to be determined concisely.

The main aim of the study is to develop a scale to measure the level at which schools stand for offering sustainable education. Also, the subgoals of the study are i) to determine teachers' views on sustainable education disposition and ii) to examine teachers' views on sustainable education disposition against school type or gender. 


\section{Method}

This study is a descriptive survey and consists of two stages. As the first step, a sustainability scale was developed by the researcher to determine the level of sustainable education. Exploratory and confirmatory factor analyzes were conducted and reliability was assessed. The scale developed here was used as a means of identifying the schools' disposition to sustainable education and whether this disposition varies depending on gender or school type variables. Relational studies, which are a type of descriptive surveys, aim at determining the degree and direction of the relationship between the variables (Frankel, Wallen \& Hyun, 2011). For this reason, the present study was planned as a relational survey since it aims to examine the level of sustainable education and its relationship with variables of gender or school type.

\section{The Developing of the Scale}

\section{Study group}

The scale developing was conducted with data collected from two different study groups. Group one consisted of primary, secondary and high school teachers working in the districts of Şarkışla and Yildizeli affiliated to Sivas province. The demographic variables of the study group are given in Table1.

\section{Table 1}

Personal Information of Study Group One

\begin{tabular}{llll}
\hline Variable & & $\mathrm{f}$ & $\%$ \\
\hline Gender & Female & 98 & 44.7 \\
& Male & 121 & 55.3 \\
\cline { 2 - 4 } School Type & Nursery School & 15 & 6.8 \\
& Primary & 84 & 38.4 \\
& Secondary & 58 & 26.5 \\
& High School & 62 & 28.3 \\
\cline { 2 - 4 } Seniority & 1-6 years & 87 & 39.7 \\
& 7-12 years & 65 & 29.7 \\
& 13-18 years & 32 & 14.6 \\
Total & 19 years and above & 35 & 15.9 \\
\hline
\end{tabular}

This study group included 98 female and 121 male participants. Of the participants; 15 work in kindergarten, 84 in primary schools, 58 in secondary schools, and 62 teach in high schools. It consisted of a total of 219 teachers, 87 of which are senior in term of 1-6 yearsof experience, 65 of whom have seniority of 7-12 years, 32 have a seniority of 13-18 years, and 35 teachers with a seniority of equal to or more than 19 years. As for the other study group, it consisted of 152 teachers working in primary, secondary and high schools in the district of Suşehri of Sivas. The group has the following demographic variables:

\section{Table 2}

Personal Information of Study Group Two

\begin{tabular}{llll}
\hline Variable & & $\mathrm{f}$ & $\%$ \\
\hline Gender & Female & 69 & 45.4 \\
& Male & 83 & 54.6 \\
\hline \multirow{2}{*}{ School Type } & Primary & 48 & 31.6 \\
& Secondary & 29 & 19.1 \\
& High School & 75 & 49.3 \\
\hline Seniority & 1-6 years & 57 & 37.5 \\
& 7-12 years & 26 & 17.10 \\
& 13-18 years & 40 & 26.13 \\
& 19 years and above & 29 & 19.07 \\
\hline Total & & 152 & $\% 100$ \\
\hline
\end{tabular}


In this group, there were 69 female and 83 male teachers, totalling to 152 teachers. Of the participants, 48 work in primary schools, 29 in secondary schools, and the rest of 75 work in high schools. As for seniority; 57 teachers have 1-6 years' experience, 26 have 7-12 years, 40 participants have a seniority of 13-18 years, and 29 of them have experience of 19 years or more.

\section{Developing of the Scale Items}

To start developing the scale of education sustainability, first of all, literature was reviewed and a pool of items was formed. During the review of literature on the concept of sustainability in the context of educational sciences, it was seen that there is abundance of studies on the use of education for a sustainable environment. However, there was seen a scarcity of theoretical studies discussing the concept of sustainability of education. It was observed that characteristics defining sustainable education have been put forward as an educational paradigm, showing functional outcomes for maintaining balance in ecological, economic and social dimensions in order to adapt to the changing world. The pool of items was drafted by referring to the literature on the role of education for a sustainable world as well as applying to professional views of two specialists of educational administration.

The body of question adapted for sustainability of education was "Misconduct by school stakeholders is discussed". After this stage, the pool of 44 items was sent to 5 specialists in the faculty of education (educational administration, educational curricula, measurement and evaluation) for revision in terms of wording, meaning, content and clarity.

\section{Analyses}

To test the validity of the scale, scope and construct validity were checked. The last draft of the scale contained 32 items. This version was applied in the primary and secondary schools located in the central district of Sivas to perform validity and reliability checks. The questionnaire was distributed to 55 teachers who wanted to participate in the study voluntarily.

As a preliminary step, the data and teachers' opinions about the application of the scale were taken as feedback. Before testing construct validity of the scale, first, results of the Kaiser-Mayer-Olkin (KMO) and Sphericity Barlett tests were examined in the first study group in order to test the conformity of the scale with construct validity check. The values such as $\mathrm{KMO}=0.94$ and Bartlett sphericity test $=4232,43 ; \mathrm{p}<0.01$ showed that the scale is eligible for factor analysis. In addition, Cronbach's Alpha coefficient was calculated from the same study group to test the reliability of the scale. Later, confirmatory factor analysis (CFA) was performed on the other study group in order to test the extent at which the scale confirms the factor structure.

The reliability of the scale was rechecked via analysis of Cronbach's Alpha coefficient in the second study group. Furthermore, analysis was conducted to find out the level of sustainable education disposition of schools and whether this level varies by gender or school type according to this scale. First of all, in reference to distortion and kurtosis values of the distribution $(-1,5,+1,5)$, the distribution was found to be normal $(-1.1,+1.00)$. Also, distortion and kurtosis values of the distribution according to gender $(-1.2,+1.1)$ and school type $(-1.0,+1.3)$ shows that distributions are normal.

There was no data loss because no extreme value was found. In the research, the level of sustainable education disposition was calculated by means of frequency, percentage, arithmetic mean and standard deviation values. The mean values obtained were interpreted as following: $0-1.7=$ low; 1.8-3.4 = moderate; $3.5-5.00=$ high level. Independent t-test was performed to determine whether the level of disposition differs depending on gender variable; while the same was checked with OneWay ANOVA test to highlight the variance, if any, for school type.

\section{Results}

\section{Results of Exploratory Factor Analysis}

The discriminatory power of the scale items was tested. The item total correlation coefficient values higher than .53 indicate discriminant items. Afterwards, the finding that the scale is suitable for construct validity as a requisite of testing the factor structure of the scale with exploratory factor analysis 
indicates that there is a high level of correlation between the variables and that the data set is suitable for factor analysis. After this stage, exploratory factor analysis (EFA) was conducted on the first study group. In factor analysis, factor load values were examined for assigning the scale items to factors or omitting them. It was found out that the factor load of each item was not less than 0.30. Consequently, the items in the scale were determined and the total variance of the scale was given below.

\section{Table 3}

Results of Exploratory Factor Analysis of the Scale

\begin{tabular}{|c|c|c|c|c|c|c|}
\hline \multirow[t]{2}{*}{ Comp. } & \multicolumn{2}{|c|}{ Initial Eigen Values } & \multicolumn{4}{|c|}{ Sum of rotated square loads } \\
\hline & Total & Variance & Cumulative $\%$ & Total & Variance & Cumulative $\%$ \\
\hline 1 & 15.57 & 48.68 & 48.68 & 7.01 & 21.91 & 21.913 \\
\hline 2 & 1.51 & 4.73 & 53.41 & 4.88 & 15.25 & 37.172 \\
\hline 3 & 1.35 & 4.21 & 57.63 & 4.56 & 14.27 & 51.449 \\
\hline 4 & 1.17 & 3.68 & 61.31 & 3.15 & 9.86 & 61.312 \\
\hline 5 & .955 & 2.98 & 64.29 & & & \\
\hline 6 & .933 & 2.91 & 67.21 & & & \\
\hline 7 & .855 & 2.67 & 69.88 & & & \\
\hline 8 & .758 & 2.36 & 72.25 & & & \\
\hline 9 & .743 & 2.32 & 74.57 & & & \\
\hline 10 & .696 & 2.17 & 76.75 & & & \\
\hline 11 & .672 & 2.09 & 78.85 & & & \\
\hline 12 & 609 & 1.90 & 80.75 & & & \\
\hline 13 & .582 & 1.81 & 82.57 & & & \\
\hline 14 & .500 & 1.56 & 84.13 & & & \\
\hline 15 & .466 & 1.45 & 85.59 & & & \\
\hline 16 & .417 & 1.30 & 86.89 & & & \\
\hline 17 & .411 & 1.28 & 88.17 & & & \\
\hline 18 & .394 & 1.23 & 89.41 & & & \\
\hline 19 & .370 & 1.15 & 90.56 & & & \\
\hline 20 & .344 & 1.07 & 91.64 & & & \\
\hline 21 & .343 & 1.07 & 92.71 & & & \\
\hline 22 & .312 & .97 & 93.68 & & & \\
\hline 23 & .305 & .95 & 94.64 & & & \\
\hline 24 & .284 & .88 & 95.52 & & & \\
\hline 25 & .229 & .71 & 96.24 & & & \\
\hline 26 & .224 & .70 & 96.94 & & & \\
\hline 27 & .205 & .64 & 97.58 & & & \\
\hline 28 & .179 & .56 & 98.14 & & & \\
\hline 29 & .177 & .55 & 98.69 & & & \\
\hline 30 & .156 & .48 & 99.18 & & & \\
\hline 31 & .138 & .43 & 99.617 & & & \\
\hline 32 & .123 & .38 & 100.000 & & & \\
\hline
\end{tabular}

According to the total variance table explained by the factor analysis, there are 4 factors whose eigenvalue is greater than 1 . The total variance of these factors is $61.31 \%$. Figure 1 shows the ScreePlot graph, which is the scattering diagram of the eigenvalues of the factors. This graph is used to determine the total number of factors of the scale. 


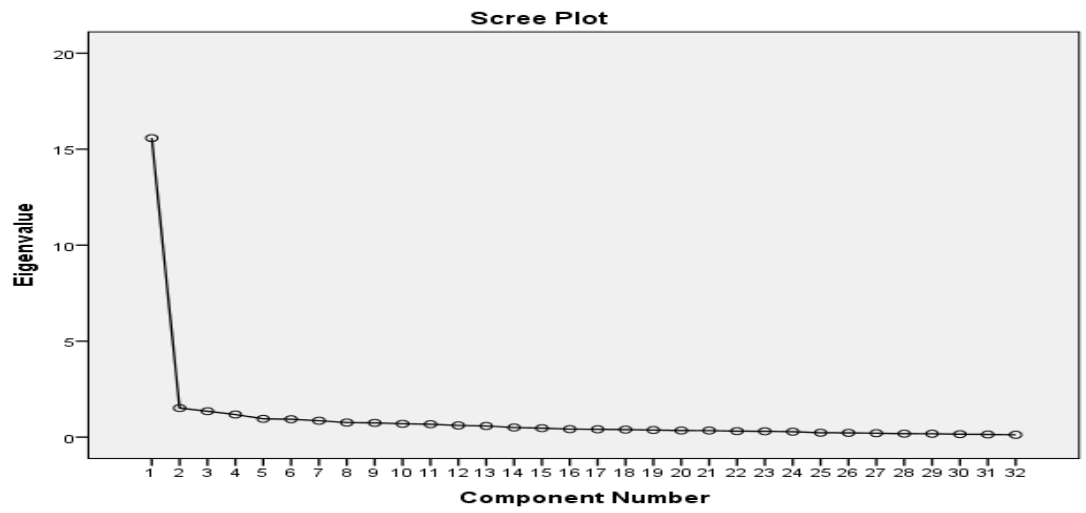

Figure 2. Scree Plot Graph of the Scale

Factors of the scale resulting from the factor analysis are required to explain at least $30 \%$ of the total variance. In the study, it was decided to have four factors with eigen value above 1 and to have a one-dimensional scale overall because the scale exceeds $30 \%$ of the total variance. The decision for unidimensional scale was based on the AFA. The factor structure of the items is as shown in the table below.

\section{Table 4}

Factor Structure of Scale Items

\begin{tabular}{ll}
\hline Components matrix & \\
\hline Items & Variances of items \\
\hline S1 & .609 \\
S2 & .602 \\
S3 & .720 \\
S4 & .692 \\
S5 & .680 \\
S6 & .644 \\
S7 & .672 \\
S8 & .759 \\
S9 & .691 \\
S10 & .682 \\
S11 & .704 \\
S12 & .737 \\
S13 & .682 \\
S14 & .728 \\
S15 & .691 \\
S16 & .550 \\
S17 & .747 \\
S18 & .728 \\
S19 & .776 \\
S20 & .807 \\
S21 & .763 \\
S22 & .693 \\
S23 & .746 \\
S24 & .763 \\
S25 & .673 \\
S26 & .503 \\
S27 & .563 \\
S28 & .731 \\
S29 & .816 \\
S30 & .704 \\
S31 & \\
S32 & \\
&
\end{tabular}


When the table was examined, it was seen that the scale explains $48.68 \%$ of the total variance at the level of sustainability of education with a one-dimensional structure. As a result of the factor structure, it was found that the common variances of the item varied between .50 and .81 . The fact that the factor load values of the scale range from .50 to .81 and have high factor loads supports a onedimensional scale structure. From these findings, the construct validity of the scale was found to be high. According to the Cronbach's Alpha test, the reliability coefficient of the scale was calculated as 0.96 . So the scale was found to be highly reliable.

\section{Results of Confirmatory Factor Analysis}

Confirmatory factor analysis (CFA) is used to check whether a defined and restricted structure is verified as a model (Maruyama, 1998). It was determined with CFA whether the explained factors were verified in the other study group. In order to test the validity of the model in the CFA, fit indices such as Chi Square Fit Test, Goodness-of-Fit-Indices (GFI), Adjusted Goodness-of-Fit Index (AGFI), Root Mean Square Residuals (RMR), and Root Mean Square Error of Approximation (RMSEA) were examined. The ratio of chi square to degree of freedom $(\chi 2 / \mathrm{df}<5)$ determined with CFA to be less than 5 indicates that the model is in good fit with real data (Sümer, 2000).

For model data fit, RMS or standardized RMS and RMSEA values are expected to be less than 0.05 , while GFI and AGFI values are expected to be higher than 0.90 . Conversely, GFI value higher than 0.85 , AGFI value above 0.80 , and RMS value lower than 0.10 are taken as criteria for the model fit with real data (Anderson \& Gerbing, 1984; Schermelleh-Engel, Moosbrugger \& Muller, 2003). The fit index values obtained from the confirmatory factor analysis conducted to check validity of the scale after exploratory factor analysis were compared aganst the criteria in the literature. For construct validity of the scale of sustainability of education, CFA was performed in the second study group. For the CFA, calculated values were as $\chi^{2}=1472.03 ; \mathrm{df}=464$ and $\mathrm{p}<.0000$. As the model revealed $\chi 2 / \mathrm{df}=$ $1472.03 / 464=3.17<5$, other fit indices of the model were examined. Other goodness-of-fit test of the model were examined by comparing against criteria in the table 5 .

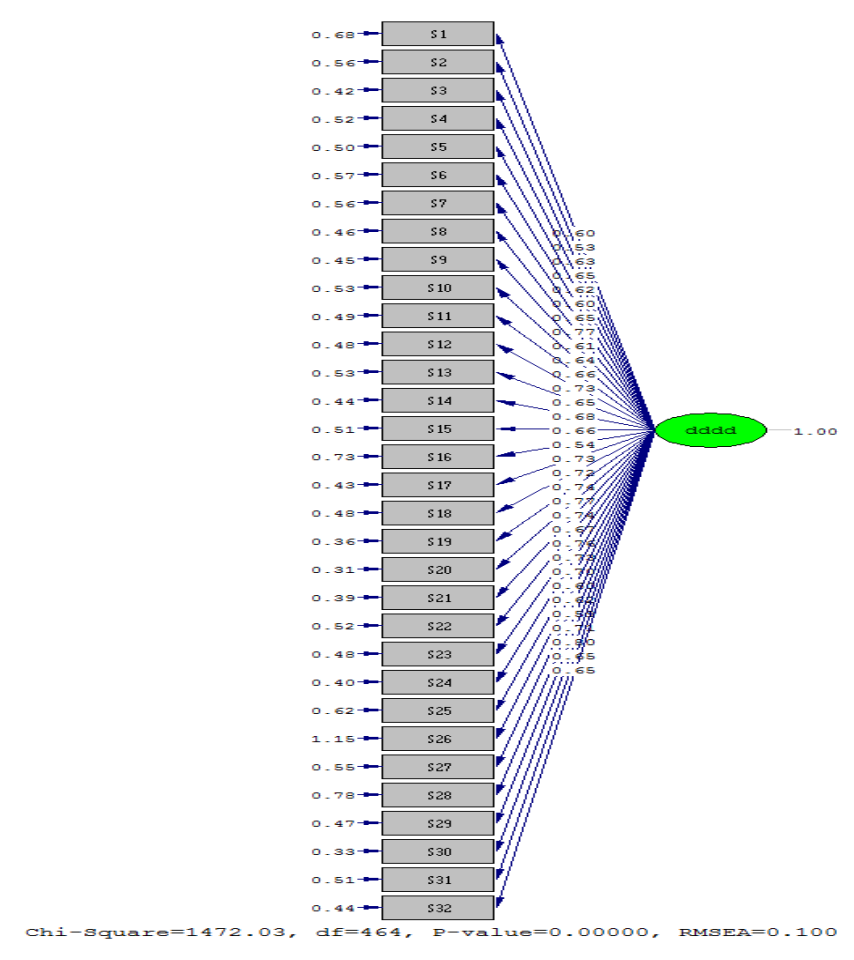

Figure 3. CFA Values of the Education Sustainability Scale 


\section{Table 5}

CFA fit index test of the model

\begin{tabular}{ccc}
\hline Goodness-of-fit test & Acceptable & Model Data \\
\hline $\mathrm{p}$ & $<.05$ & 0.000 \\
$\chi 2 / \mathrm{df}$ & $<5$ & 3.17 \\
$\mathrm{RMSEA}$ & $<.010$ & 0.10 \\
$\mathrm{RMR}$ & $<.05$ & .05 \\
$\mathrm{NFI}$ & $>.95$ & .94 \\
$\mathrm{CFI}$ & $>.95$ & .96 \\
\hline
\end{tabular}

When the values in the table are examined, the values of RSMSEA, RMR and NFI values are not found within the acceptable range. Therefore, modification was applied on items that will decrease the chi square value. The resulting CFA x$/ 2 d$ is displayed in the figure and other goodness-of-fit test are shown in the table below.

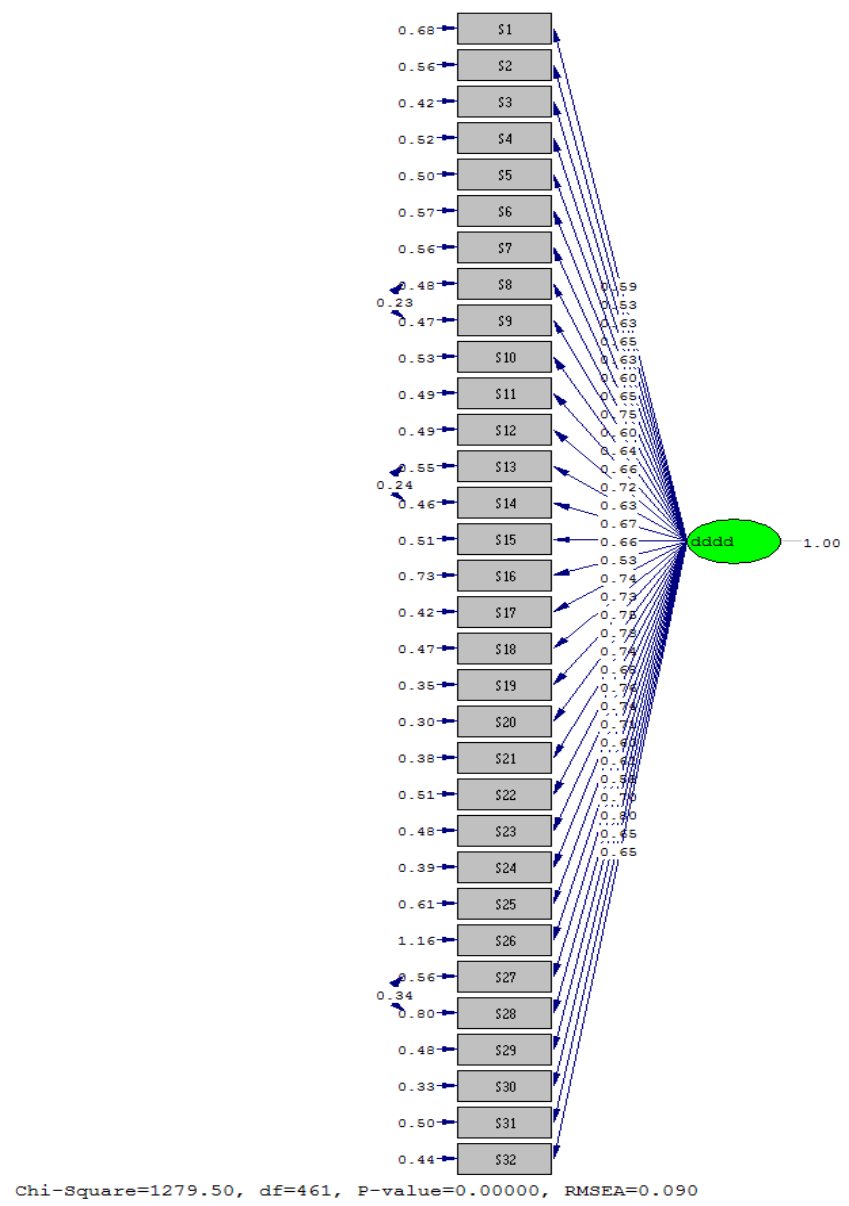

Figure 4. CFA values of the Educational Sustainability Scale (Modification Values)

As seen in the figure, the modification yielded the value of $\mathrm{x}^{2} / \mathrm{sd}=1279.50 / 461=2.77$ and RMSEA $=0.09$. As a result of the modification, the other goodness-of-fit test appears as in the table 6 below. It was observed that the goodness-of-fit test calculated from the CFA fall within the range of acceptable values. 


\section{Table 6}

CFA fit index test of the model (Modification Values)

\begin{tabular}{ccl}
\hline Goodness-of-fit test & Acceptable & Model Data \\
\hline $\mathrm{p}$ & $<.05$ & 0.000 \\
$\mathrm{X}^{2} / \mathrm{sd}$ & $<5$ & 2.77 \\
$\mathrm{RMSEA}$ & $<.010$ & 0.09 \\
$\mathrm{RMR}$ & $<.05$ & .05 \\
$\mathrm{NFI}$ & $>.95$ & .95 \\
$\mathrm{CFI}$ & $>.95$ & .97 \\
\hline
\end{tabular}

It was seen that the error variances in the analysis vary between .33 and .76 and factor loads vary from .33 to .76 . These findings all together imply that the scale of sustainability of education is verified. It satisfies the necessary fit indices.

\section{Results of Reliability}

For reliability of the education sustainability scale, Cronbach's Alpha coefficient was examined. The reliability coefficient of the scale was calculated as .96. It indicates a highly reliable scale. Once reliability and validity of the scale were ensured, 5-point rating type was used $(1=$ Totally Disagree, $2=$ Sisagree, $3=$ Agree, $4=$ Partially Agree, $5=$ Completely Agree). The minimum and maximum scores in the scale are 32 and 160, respectively. Higher scores obtained from the scale refer to increased sustainability of education.

\section{Statistical Findings about Disposition to Sustainable Education}

First of all, teachers' views about the disposition to sustainable education was determined by the developed scale. The findings are given in table 7.

Table 7

\begin{tabular}{lllll}
\hline $\mathrm{N}$ & $\max$ & $\min$ & $\bar{x}$ & $\mathrm{Sd}$ \\
\hline 370 & 4.1 & 3.3 & 3.8 & .6 \\
\hline
\end{tabular}

According to the teachers' views, the standard deviation (sd) for the level of sustainable education disposition was calculated as .6 and the mean as 3.8. So it can be inferred that the teachers have a high level of disposition to sustainable education. The results of independent t-test on whether teachers' views differ according to gender variable are as shown in the table 8 .

\section{Table 8}

Analysis of Teachers' Views on Sustainable Education Disposition by Gender

\begin{tabular}{llllll}
\hline & $\mathrm{N}$ & $\overline{\boldsymbol{x}}$ & $\mathrm{Sd}$ & $\mathrm{t}$ & $\mathrm{p}$ \\
\hline Female & 167 & 3.72 & .51 & -3.62 & .000 \\
Male & 203 & 3.98 & .48 & & \\
\hline
\end{tabular}

As can be seen in the table 8 , it was found out that teachers' views on sustainable education disposition differ between genders $(\mathrm{t}=-3.62, \mathrm{p}<.05)$ in favor of males. In other words, male teachers hold more positive views on sustainable education disposition compared to their female peers. The results of ANOVA test regarding whether teachers' opinions differ by type of school are as shown in the table 9 below.

As it can be seen in the table 9, it was found out that opinions of teachers regarding sustainable education disposition do not differ according to type of school $\left(\mathrm{F}_{(2-367)=} .53, \mathrm{p}>.05\right)$. That is to say, teachers working in different types of schools hold similar views regarding sustainability of education. 


\section{Table 9}

Analysis of Teachers' Opinions regarding Sustainable Education Disposition by Type of School

\begin{tabular}{lllcccc}
\hline School Type & $\mathrm{N}$ & & Sum of Squares & Mean Square & $\mathrm{F}$ & $\mathrm{p}$ \\
\hline Primary & 83 & Between- groups & .51 & .25 & .53 & \\
Secondary & 137 & Intragroup & 176.90 & .48 & & \\
High School & 150 & Total & 177.41 & & & \\
\hline
\end{tabular}

\section{Discussion, Conclusion and Recommendations}

This study was carried out to design an instrument of measurement about disposition to sustainable education. After the scale was prepared, the level of disposition to sustainable education level was investigated by means of teachers' views. At the same time, it was examined whether or not these levels differ according to the variables such as type of school or gender.

The study started with a review of literature for preparing the pool of items to be included in the scale on sustainability of education. The literature review was performed for education for sustainability since only a limited amount of literature is available specifically about our concern. Then statements which explain the concept of sustainable education and which indicate the existence of sustainable education were drafted by the researcher and revised in the light of expert opinions. Explanatory factor analysis was performed with the data and the scale was found to be one-dimensional with 32 items. After the explanatory process, the goodness-of-fit test was found within the acceptable limits. According to the reliability tests obtained from both study groups, the scale was found to be reliable.

The scale of sustainable education disposition is expected to contribute to the particular field because it is an important term which has universal implications, handles the phenomena in the core of education, and discusses problems recently coming onto the agenda in relation with the matter of sustainability from an educational perspective. Sandel, Öhman and Östman (2005) state that every single person plays a role in achieving sustainable development and that this role lies at the base of nature, school and democracy. In this regard, it seems important to use a valid and reliable measurement tool to test the implementation of sustainable life in the context of education. The scale of sustainable education disposition is an instrument which helps understand the extent at which the existing education system seems eligible for sustainable education. For eliminating obstacles before sustainable education, changes in one dimension only may not be enough. It might be needed to put into life changes in many other dimensions, such as teacher qualifications, educational policies, educational economics, programs, management and philosophy. Sund and Wickman (2008) suggest that teachers should have better teaching methods for sustainable development. They add that if teachers express their wish to change teaching practices for reflective teaching, it would bring about the same expectation for sustainable education. In order for the current generation to keep up with the changing world conditions and for the education provided to apply to the next generation, sustainable education could be utilised. If education continues to be used as a political tool to create a predetermined society, we might be faced with the risk of education losing its emancipatory and democratizating potential (Jickling, 2003). In contemporary education, many studies have linked a teacher-student perspective and a shared responsibility for learning between teachers and students with the idea of sustainability (Scott \& Gough 2003).

It can be suggested that, once the status of schools (according to the size of school, location, school culture and climate, school type, etc.), as sub-elements of the system, is determined; the status of other dimensions can be disclosed so that conditions of sustainable education can be set out. In particular, efforts to be exerted by experts in different disciplines to achieve sustainable education can help to make the issue more concrete. In this regards, sustainable education refers to a universally sustainable education approach rather than practice in a single city, region or country because it is based on an educational paradigm that each individual lives in a balance in the world and that each individual is responsible for the place where he lives. Wals and Jickling (2000), Lijmbach et al. (2002), Rauch (2002) and Stables and Scott (2002), in diverse ways though, put forward that, towards the goal of attaining 
sustainable development, free-thinking as a result of the democratic mission of universal education and operational competence of this mission would represent the essential components of the future. Still, there is an obstacle beyond that, which is the fact that human habits affect sustainability (Wickman, 2004).

Utilizing the sustainable education disposition scale in national and international contexts could determine the local and universal conditions for disposition to sustainable education. It will also allow comparison of the analyses on validity and reliability of the scale. Determining the level of sustainable education disposition can in turn provide clues about changes to be applied in the education system. Predominantly in developed countries (England, Canada, Sweden, Finland, etc.), it has automatically come to the agenda to make changes in teaching methods, educational contents, and teacher qualifications in various educational paradigms since these states seem to focus on education for sustainabile development.

This study has revealed that teachers' views indicate a high disposition to sustainable education in the current status. Also, it was concluded that teachers' views on sustainable education disposition showed a significant difference against gender variable but did not show a significant difference by school type. Male teachers have higher disposition in sustainable education than female teachers. Still, teachers' views on sustainable education disposition do not seem to change in different types of schools. At the moment, it seems unlikely to make an evaluation or comparison on this issue, since no other example comparable to this study was accessible in the literature.

Last but not the least, the measurement tool developed to determine the sustainable education disposition as the first step of achieving sustainability in education system is likely to contribute to not only the literature but also practitioners with information about the quality of education. In the future, the use of scale to determine the level of sustainable education disposition in distinct settings will serve to reach clearer and more precise results since it will help generalize the results of the present study. Moreover, departing from the relationship between sustainabile education and various disciplines, it is recommended to study the concept at interdisciplinary scale engaging educational sciences and social sciences at the same time (economy, sociology etc.) based on the relationship of sustainable education with different disciplines. This study was carried out with quantitative method. However, qualitative studies or mixed method studies could be conducted so that they can mediate concretization of sustainable education.

\section{References}

Anderson, J. C. \& Gerbing, D. W. (1984). The effect of sampling error on convergence, improper solutions, and goodness-of-fit indices for maximum likelihood confirmatory factor analysis. Psychometrika, 49 (2), 155-173.

Andersson, K., Jagers, S.C., Lindskog, A. \& Martinsson, J. (2013). Learning for the future? Effects of education for sustainable development (ESD) on teacher education students. Sustainability, 5, 5135-5152.

Becker, G. S. \& Chiswick, B. R. (1966). Education and the distribution of earnings. The American Economic Review, 56(1/2), 358-369.

Blowers, A. (2003). Environmental planning for sustainable development. (Blowers, A.\& Evans, B., Eds). In Town Planning into the 21 st Century. London: Routledge, pp. 33-54.

Brand, K.W. (2002). Politik der nachhaltigkeit: voraussetzungen, probleme, Berlin: Edition Sigma.

Cebrián, G. \& Junyent, M. (2015). Competencies in education for sustainable development: Exploring the student teachers' views. Sustainability, 7, 2768-2786.

Chalkley, B., Haigh, M., \& Higgitt, D. (2013). Education for sustainable development: papers in honour of the United Nations Decade of Education for Sustainable Development (2005-2014). New York: Routledge.

Chapin III, F. S., Torn, M. S., \& Tateno, M. (1996). Principles of ecosystem sustainability. TheAmericanNaturalist, 148(6), 1016-1037. DOI. 10.1086/285969 
Cohen, M. (1988). Restructuring the Education System: Agenda for the 1990s. Washington DC: National Governors' Association.

Esteva, G. (2010). Development. (Wolfgang. S. Ed.) In the development dictionary: A guide to knowledge as power, London: Zed Books, pp. 1-24.

Finkbeiner, M., Schau, E. M., Lehmann, A., \& Traverso, M. (2010). Towards life cycle sustainability assessment. Sustainability, 2(10), 3309-3322.

Frankel, J. R., Wallen, N. E. \& Hyun, H. H. (2011). How to design and evaluate research in education (8. press).: New York: McGraw-Hill Companies.

Jickling, B. \& Wals, A.E.J. (2007). Globalization and environmental education: Looking beyond sustainable development. Journal of Curriculum Studies 40(1), 1-21.

Lenz, C. (2013). Sürdürülebilir demokratik toplumlar için eğitimin kilit rolü. [The key role of education for sustainable democratic societies] (Trans. M. G., Tamer) Journal of Social Sciences Institute of Hitit University, 6(2), 103-110.

Lijmbach, S., Van Arcken, M.M., Van Koppen, C. S. A.\& Wals, A. E. (2002). Your view of nature is not mine'. Learning about pluralism in the classroom, Environmental Education Research, 8(2), $121-135$.

Maruyama, G. M. (1998). Basics of structural equation modeling. Thousand Oaks, CA: Sage Publishing.

Ohman, J., Ostman, L., \& Sandell, K. (2005). Education for sustainable development: Nature, school and democracy. Lund: Studentlitteratur.

Pauw, J.B.-D., Gericke, N., Olsson, D. \& Berglund, T.(2015). The effectiveness of education for sustainable development. Sustainability, 7, 15693-15717.

Rauch, F. (2002). The potential of education for sustainable development for reform in schools. Environmental Education Research, 8 (1), 43-51.

Resnick, L. B., \& Hall, M. W. (1998). Learning organizations for sustainable education reform. Daedalus, 127(4), 89-118.

Sachs, W. (Ed.). (1997). Development dictionary, The: A guide to knowledge as power. India: Orient Blackswan.

Schermelleh-Engel, K., Moosbrugger, H., \& Müller, H. (2003). Evaluating the fit of structural equation models: Tests of significance and descriptive goodness-of-fit measures. Methods of psychological research online, 8(2), 23-74.

Scott, W. \& Gough, S. (2003). Sustainable development and learning: Framing the issues, London: Routledge Falmer.

Spahiu, M.H. \& Lindemann-Matthies, P. (2015). Effect of a toolkit and a one-day teacher education workshop on esd teaching content and methods. A study from Kosovo. Sustainability, 7, 80518066.

Stables, A.\& Scott, W. (2002). The quest for holism in education for sustainable development, Environmental Education Research, 8(1), 53-60.

Sterling, S. (2001). Sustainable Education: Re-Visioning Learning and Change. Schumacher Briefings, Dartington: Green Books.

Sümer, N. (2000). Yapısal eşitlik modelleri: Temel kavramlar ve örnek uygulamalar. [Structural equation models: Basic concepts and sample applications]. Turkish psychology writings,3(6), 4974.

Sund, P. \& Wickman, P. O. (2008). Teachers' objects of responsibility: something to care about in education for sustainable development? Environmental Education Research, 14(2), 145-163.

Tyack, D. B. (1974). The one best system: A history of American urban education (Vol. 95). Cambridge: Harvard University Press, ISBN 9780674637825 
Uhl, C., Kulakowski, D., Gerwing, J., Brown, M., \& Cochrane, M. (1996). Sustainability: A touchstone concept for university operations, education, and research. Conservation Biology, 10(5), 13081311.

UNESCO (2009). Education for Sustainable Development 2009. Available online. http://portal.unesco.org/education/en/ev.phpURL_ID=23295\&URL_DO=DO_TOPIC\&URL_SE CTION=201.html. (Accessed on 25 October 2017).

Wals, A.E.J. \& Jickling, B.(2000). Process-based environmental education: setting standards without standardising. (Jensen, B.B., Schnack, K. \& Simovska, V. , Eds) In Critical Environmental and Health Education, Copenhagen, Research issues and challenges, pp. 127-149.

Wheeler, K. A. \& Bijur, A. P. (2000). Education for a sustainable future: a paradigm of hope for the 21 st century (Vol. 7). New York: Kluwer Academic/Plenum Publishers, ISBN. 978-1-4615-42773.

Wickman, P.-O. (2004). The practical epistemologies of the classroom: A study of laboratory work. Science Education, 88, 325-344.DOI. 10.1002/sce.10129

Wolff, L.-A., Sjöblom, P., Hofman-Bergholm, M.\& Palmberg, I. (2017). High Performance Education Fails in Sustainability? A Reflection on Finnish Primary Teacher Education. Education. Sciences, 7, 32 . 
Appendix 1

Sustainable Education Disposition Scale

Dear Participants,

This study aims to determine the sustainability level of education. Your thoughts are invaluable, for they contribute well to the results of this study. Therefore, I request you to give your replies to the items below by marking $(\mathrm{X})$ options that best suit you. Thank you very much in anticipation.

Gender : Female () Male ()

School Type : Primary School ( ) -Secondary School ( ) - High School

\begin{tabular}{|c|c|c|c|c|c|c|}
\hline No & $\begin{array}{l}\text { ITEMS } \\
\text { In this school, }\end{array}$ & 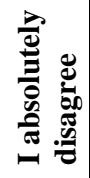 & 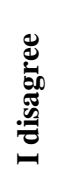 & 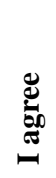 & 尝 & 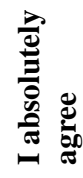 \\
\hline 1. & $\begin{array}{l}\text { Democratic participation is ensured in the } \\
\text { implementation of the decisions made. }\end{array}$ & & & & & \\
\hline 2. & Teachers and students are conscious of learning to learn. & & & & & \\
\hline 3. & $\begin{array}{l}\text { Teachers and students embrace the attempts towards } \\
\text { change. }\end{array}$ & & & & & \\
\hline 4. & $\begin{array}{l}\text { School and its environment are integrated for expert, } \\
\text { resource and learning in school-environment } \\
\text { relationships. }\end{array}$ & & & & & \\
\hline 5. & $\begin{array}{l}\text { Students are made to be sensitive towards the needs and } \\
\text { rights of the next generations. }\end{array}$ & & & & & \\
\hline 6. & $\begin{array}{l}\text { Replies to the questions "How far have we come so far?" } \\
\text { and "How far more do we want to go?" are sought by } \\
\text { school stakeholders. }\end{array}$ & & & & & \\
\hline 7. & $\begin{array}{l}\text { Educators are aware that every little positive change } \\
\text { contributes to the whole school. }\end{array}$ & & & & & \\
\hline 8. & $\begin{array}{l}\text { Education provided to students enable them to be future- } \\
\text { oriented upon making decisions. }\end{array}$ & & & & & \\
\hline 9. & $\begin{array}{l}\text { Students are made to make connections between their } \\
\text { daily life and global-environmental problems. }\end{array}$ & & & & & \\
\hline 10. & $\begin{array}{l}\text { Education is based on making students sensitive about } \\
\text { leading a balanced life with animals and the nature. }\end{array}$ & & & & & \\
\hline 11. & Students are taught the ways of learning to live together. & & & & & \\
\hline 12. & $\begin{array}{l}\text { Studies that teach critical and creative thinking skills to } \\
\text { students are focused more. }\end{array}$ & & & & & \\
\hline 13. & $\begin{array}{l}\text { Learning outcomes are taught by associating local with } \\
\text { global and the links of past-present-future. }\end{array}$ & & & & & \\
\hline
\end{tabular}




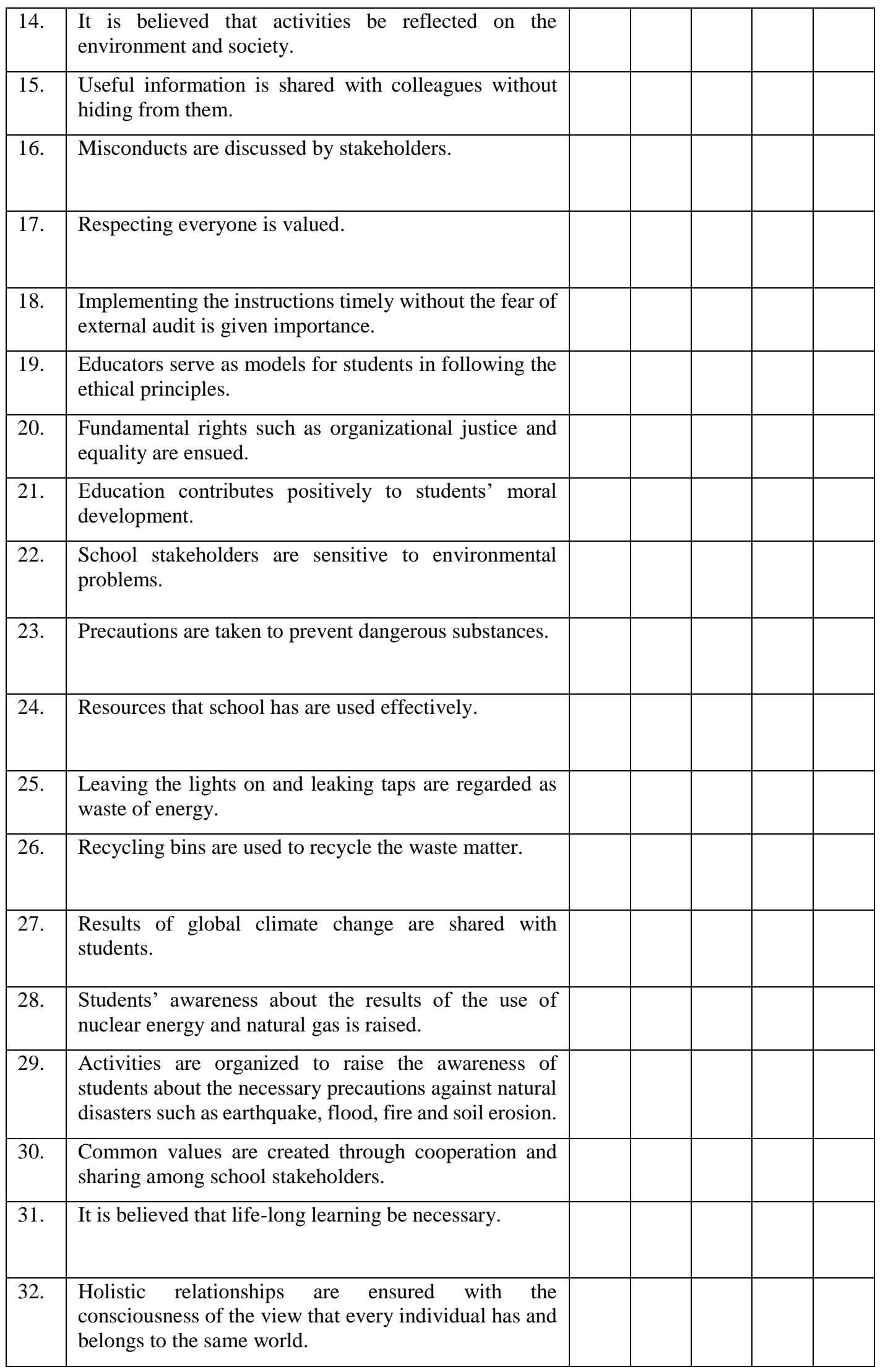


